\title{
Analysis of lead (Pb) levels in water, sediment and mollusks in secondary irrigation channels in Gorontalo Province, Indonesia
}

\author{
ISMAWATI A. TAHIR, DJUNA LAMONDO, DEWI WAHYUNI K. BADERAN \\ Department of Biology, Faculty of Mathematics and Natural Sciences, Universitas Negeri Gorontalo. Jl. Prof. B.J. Habibie, Tilongkabila, Bone Bolango \\ 96583, Gorontalo, Indonesia. Tel./fax.: +62-435-821752, `email: dewi.baderan@ung.ac.id, tikatahir1998@gmail.com
}

Manuscript received: 2 December 2020. Revision accepted: 11 June 2021

\begin{abstract}
Tahir IA, Lamondo D, Baderan DWK. 2021. Analysis of lead (Pb) levels in water, sediment and mollusks in secondary irrigation channels in Gorontalo Province, Indonesia. Intl J Bonorowo Wetlands 11: 1-6. This study was conducted in July-August 2020 in the secondary irrigation channels of Gorontalo Province aimed to determine the lead content in the water, sediment, and gastropods in the channels. The sampling points were located in four sub-districts, i.e., North Bulango Sub-district, Sipatana Subdistrict, Central City Sub-district, and Hulonthalangi Sub-district. The samples were analyzed using Atomic Absorption Spectrophotometer (AAS). The data were analyzed qualitatively by comparing them with the contamination thresholds set by the government of Indonesia. The results showed that the levels of lead in water in the four stations were $0.37 \mathrm{mg} / \mathrm{L}, 1.30 \mathrm{mg} / \mathrm{L}, 1.69 \mathrm{mg} / \mathrm{L}$, and $0.38 \mathrm{mg} / \mathrm{L}$, respectively, in the sediment $1.1268 \mathrm{ppm}, 0.9719 \mathrm{ppm}, 0.7602 \mathrm{ppm}$, and $0.5290 \mathrm{ppm}$, respectively, and in each mollusk species, i.e., Bellamnya sp. $0.2924 \mathrm{mg} / \mathrm{kg}$, Pomacea canaliculata $0.2413 \mathrm{mg} / \mathrm{kg}$ and Pomacea canaliculata $0.1873 \mathrm{mg} / \mathrm{kg}$. The lead levels in the water, sediment, and gastropods in the study sites exceeded the contamination thresholds set by the Indonesian government.
\end{abstract}

Keywords: Lead, mollusks, secondary channels, sediment, water

\section{INTRODUCTION}

Irrigation channels are built to distribute and supply water to agricultural areas, especially rice fields, to maintain high agricultural production. According to the Government Regulation of the Republic of Indonesia Number 20 of 2006, irrigation channels are divided into 3, namely, primary, secondary, and tertiary irrigation channels. A secondary irrigation channel is a channel that carries water from the primary irrigation channel to the tertiary irrigation channel.

The secondary irrigation channels from the Lomaya dam are 25,733 meters long (Biahimo et al. 2015), passing through settlements and houses. Some residents who live along the secondary irrigation channels dispose of household waste, such as liquid waste, batteries, children's toys, wall paint, and plastic food or beverage packaging, to the irrigation channels. The materials discharged into this irrigation channel are likely to contain heavy metal lead $(\mathrm{Pb})$, as Lamondo (2020) stated that batteries, children's toys, wall paint, and plastics contain lead. Eshmat et al. (2014) also reported that heavy metal pollutants, i.e., lead $(\mathrm{Pb})$ and cadmium $(\mathrm{Cd})$, that occurred in Ngemboh waters were caused by the disposal of resident waste originating from organic and inorganic materials.

The secondary irrigation channels become a place for liquid waste disposal from motor vehicle washing businesses and workshops. This liquid waste is likely to contain lead as research by Nadeak et al. (2015) showed that the liquid waste in motorized vehicle workshops in the city of Tanjungpinang observed at 3 small workshops with
3 sampling points had lead levels exceeding the threshold of more than $0.1 \mathrm{mg} / \mathrm{L}$.

The secondary irrigation channels also receive waste from agriculture in the form of fertilizers and pesticides, which are likely to contain lead. Research conducted by Sukarjo et al. (2018) showed that applying fertilizer to rice plants could increase the metal content of lead and cadmium in soil and rice plants.

The secondary irrigation channels are also close to highways with heavy traffic of motor vehicles that produce smoke containing $\mathrm{Pb}$. This smoke will crystallize in the air, and when it rains, the lead will be carried away with rainwater and enter the waterways. Pratama et al. (2012) showed that the lead metal content in Tapak River water ranged from 0.01 to $1.11 \mathrm{ppm}$. This was thought to have come from the motorized vehicle pollutants in the water bodies and smoke from the factories around the river.

The secondary irrigation water is also used to irrigate rice fields. Suppose this irrigation water is polluted and used to irrigate rice fields. In that case, the lead will accumulate in agricultural crops, and it will accumulate in the fish and gastropods, which will cause metabolic and respiratory disorders.

Suppose humans consume animals and plants that have been contaminated with lead. In that case, the lead will accumulate in the body, causing health problems such as weakness, headaches, fatigue, tingling hands, anemia, renal dysfunction, physiological dysfunction, liver dysfunction, and decreased fertility. Research by Lamondo et al. (2015) on male reproduction showed that lead could cause apoptosis in spermatogenic cells. 
Heavy metals in the water will settle and accumulate in the sediment, so sediment is often used to indicate environmental pollution. Wicaksono et al. (2016) state that as the heavy metal content in the water settles in the sediment, the concentration of lead in the water will decrease. This is supported by Saputra's research (2018) which showed that the lead content in the sediment was $2.95 \mathrm{ppm}$, more significant than that in the water, i.e., $0.0183 \mathrm{ppm}$. This can occur because heavy metals entering water bodies will experience deposition and dilution, then accumulate in aquatic biota.

Besides water and sediment, biota can also be used as a bio-indicator of lead pollution in secondary channels. Baderan et al. (2019) state that gastropods that live on the bottom of waters can be used as bioindicators of pollution because filter feeders have low mobility and a high tolerance for environmental pollution.

\section{MATERIALS AND METHODS}

\section{Study area}

This study was conducted from July to August 2020 in Lomaya irrigation secondary channels, Gorontalo, Indonesia, with a length of $25.733 \mathrm{~m}$. Samplings were done in 4 observation stations (Figure 1). (i) Station I is the entry point for the secondary channel (Inlet) river water; the location is at the Lomaya dam, Lomaya Village, North Bulango Sub-district, Bone Bolango District. (ii) Station II is a secondary channel for receiving household waste and washing motor vehicles; the location is at Jalan Tondano, Bulotadaa Barat Village, Sipatana Sub-district, Gorontalo City. (iii) Station III is a secondary channel for receiving household waste, workshops, agricultural waste, and washing motor vehicles; the location is at Jalan Arif
Rahman Hakim, Dulalowo Village, Kota Tengah Subdistrict, Gorontalo City. (iv) Station IV is where water comes out from the secondary channel (outlet) at Jalan Yos Sudarso, Tenda Village, Hulonthalangi Sub-district, Gorontalo City.

\section{Procedure}

\section{Preparation of samples}

Water test sampling for lead inspection: (i) the sampling point area was determined, (ii) the jerry cans were rinsed 2-3 times with sample water, (iii) water sample was taken using a $600 \mathrm{~mL}$ jerry can (Kitong et al. 2012).

Sediment sampling for lead examination: (i) the sampling area point was set, (ii) sediment was taken using a paralon pipe vertically, (iii) the sediment obtained was separated, cleaned from other objects, and inserted into the plastic (Rangkuti 2009).

A sampling of golden snails for lead examination: (i) the sampling area was determined by plotting the size of 1 $\mathrm{m} \times 1 \mathrm{~m}$, (ii) the snails were taken and put into a plastic container that had been labeled and put into a coolbox (Nur et al. 2015).

\section{Water sample preparation (SNI 6989.8:2009)}

Fifty milliliters of water were put in a $100 \mathrm{~mL}$ Erlenmeyer, added $5 \mathrm{~mL}$ of concentrated $\mathrm{HNO}_{3}$ then covered using a funnel. Then, it was heated slowly until the remaining volume was $15-20 \mathrm{~mL}$ until it formed a slightly white precipitate or the solution became clear. Then the funnel was rinsed, and the rinsing water was put into a beaker. The solution was then transferred into a $50 \mathrm{~mL}$ volumetric flask, added with distilled water to the mark, and then homogenized. Then the solution was ready for analysis using AAS.

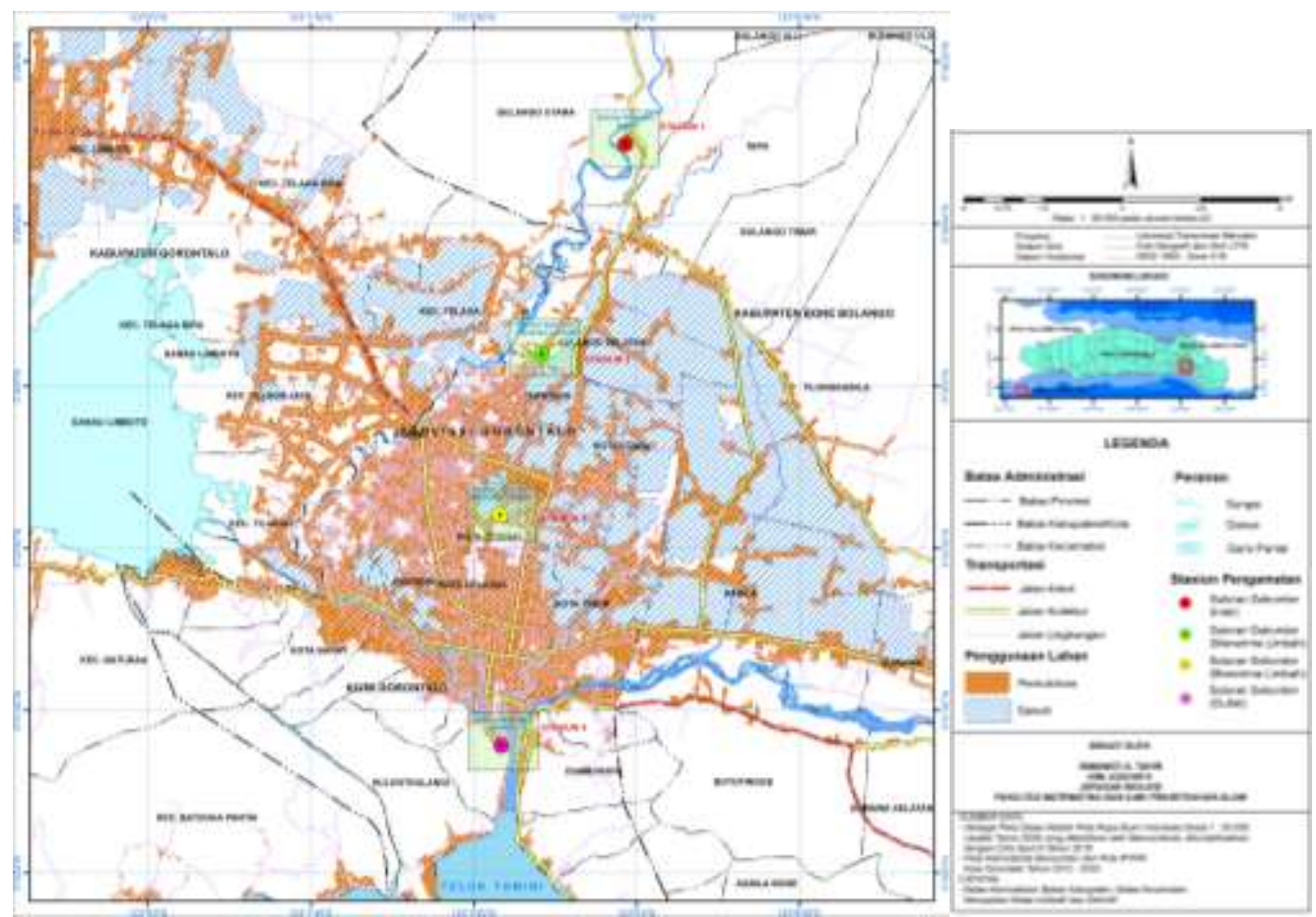

Figure 1. Research sampling locations 
Sediment sample preparation (SNI 06-6992.3-2004)

The dry sediment as much as 3 grams was weighed and put in the Erlenmeyer, then added with $25 \mathrm{~mL}$ of distilled water and stirred using a stirring rod. Next. 5-10 mL of concentrated $\mathrm{HNO}_{3}$ was added, stirred, then added with 3-5 boiling stones, and then closed using a watch glass. Then Erlenmeyer was heated on a hot plate at a temperature of $105^{\circ} \mathrm{C}-120^{\circ} \mathrm{C}$ until the volume of the remaining solution was $10 \mathrm{~mL}$. It was then added with $5 \mathrm{~mL}$ of nitric acid, 5 $\mathrm{mL}$ of concentrated $\mathrm{HNO}_{3}, 3 \mathrm{~mL}$ of perchloric acid, $3 \mathrm{~mL}$ of concentrated $\mathrm{HCLO}_{4}$. Then it was reheated in an electric bath until the lead smoke was white and the test sediment solution became clear; then, it was heated again for 30 minutes, then the sediment sample was cooled and filtered with filter paper with a pore size of $8.0 \mathrm{~m}$. Furthermore, the sediment sample filtrate results were put into a $100 \mathrm{~mL}$ volumetric flask, and distilled water was added to the mark. Then it was ready to be tested using AAS.

\section{Snail sample preparation (SNI 2354.5-2011)}

The snail was weighed as much as 5 grams. Then, a spiked solution of $0.05 \mathrm{mg} / \mathrm{kg}$ (the result of a mixture of snail and $0.25 \mathrm{~mL}$ of standard $\mathrm{Pb}$ solution) was made, then evaporated on a hot plate with a temperature of $100^{\circ} \mathrm{C}$ until dry. The sediment and spiked were inserted into the ash furnace in stages from $100^{\circ} \mathrm{C}-450^{\circ} \mathrm{C}$ every 30 minutes to 18 hours. Then it was cooled at room temperature and added with $1 \mathrm{~mL}$ of $\mathrm{HNO}_{3} 65 \%$; then, the solution was homogenized, then it was evaporated again on a hot plate at $100^{\circ} \mathrm{C}$ until dry. Next, the snail and Spiked samples were put back into the ashing furnace, and the temperature was gradually increased to $100^{\circ} \mathrm{C}$ every 30 minutes until the temperature reached $450^{\circ} \mathrm{C}$, and maintained for 3 hours. After the ash turned white, the snail and spiked samples were cooled to room temperature. As much as $5 \mathrm{~mL}$ of $6 \mathrm{M}$ HCL was added to each snail sample, spiked was homogenized until the ash dissolved in the acid. Then it was reheated on the hot plate at $100^{\circ} \mathrm{C}$ until dry. Then 10 $\mathrm{mL}$ of $0.1 \mathrm{M} \mathrm{HNO}_{3}$ was added and chilled for 1 hour; then, the solution was transferred to a $50 \mathrm{~mL}$ polypropylene. Modifier matrix solution was measured and added to the limit mark. The sample was ready to be tested using AAS.

\section{Data analysis}

The concentrations of lead in the water were compared with the quality standards set in Government Regulation no. 82 of 2001 concerning water quality management and water pollution control, which is $0.03 \mathrm{mg} / \mathrm{L}$, the concentrations of lead in sediments were compared with quality standards set in the Decree of the Minister of Environment No. 51 of 2004. The lead concentrations in snails were compared with the quality standard set in SNI 7387: 2009 regarding the maximum limit of heavy metal contamination in food.

\section{RESULTS AND DISCUSSION}

\section{Lead levels in water}

The lead levels in the water were different among stations (Figure 2). The water in station III had the highest level of lead, i.e., $1.69 \mathrm{mg} / \mathrm{L}$, while the water in the station I had the least, i.e., $0.37 \mathrm{mg} / \mathrm{L}$.

\section{Levels of lead in sediment}

The lead contents in the sediment were different among stations. The sediment in the station I had the highest level of lead, i.e., $1.1268 \mathrm{mg} / \mathrm{kg}$, while the water in station IV was the least, i.e., $0.5290 \mathrm{mg} / \mathrm{kg}$ (Figure 3).

\section{Levels of lead in mollusks}

Mollusks were found only in stations II and III. In station II, 2 species of gastropods were discovered, namely Bellamnya sp. and Pomacea canaliculata, and in station III, only Pomacea canaliculata was found. The lead levels of each species at station II were $0.2924 \mathrm{mg} / \mathrm{kg}$ and 0.2413 $\mathrm{mg} / \mathrm{kg}$, respectively, and at station III, $0.1873 \mathrm{mg} / \mathrm{kg}$ (Figure 4).

\section{Environmental parameters}

The water temperature at 4 stations ranged from $24^{\circ} \mathrm{C}$ to $30^{\circ} \mathrm{C}$ with an average of $27.5^{\circ} \mathrm{C}$. The $\mathrm{pH}$ of the water was the same for all stations, i.e., 7. Dissolved oxygen levels differed among the four stations: at the station I, it was $4.8 \mathrm{mg} / \mathrm{L}$, station II $3.1 \mathrm{mg} / \mathrm{L}$, station III $1.3 \mathrm{mg} / \mathrm{L}$, and station IV $4.0 \mathrm{mg} / \mathrm{L}$ (Figure 5). The average value of dissolved oxygen level at the four stations was $3.3 \mathrm{mg} / \mathrm{L}$.

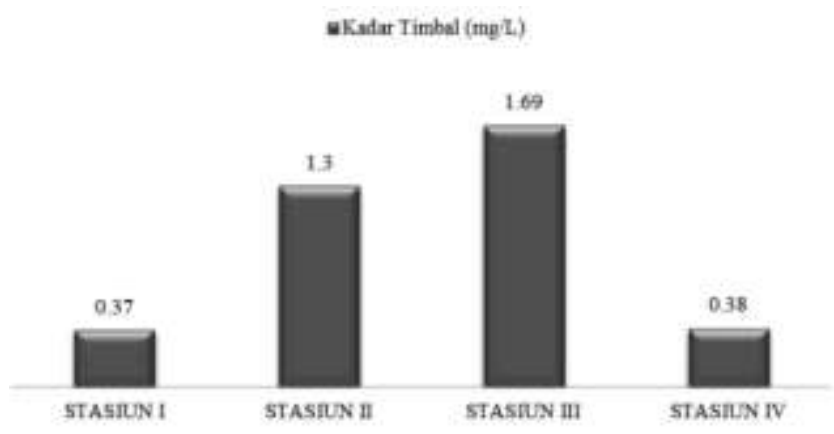

Figure 2. Lead content in water

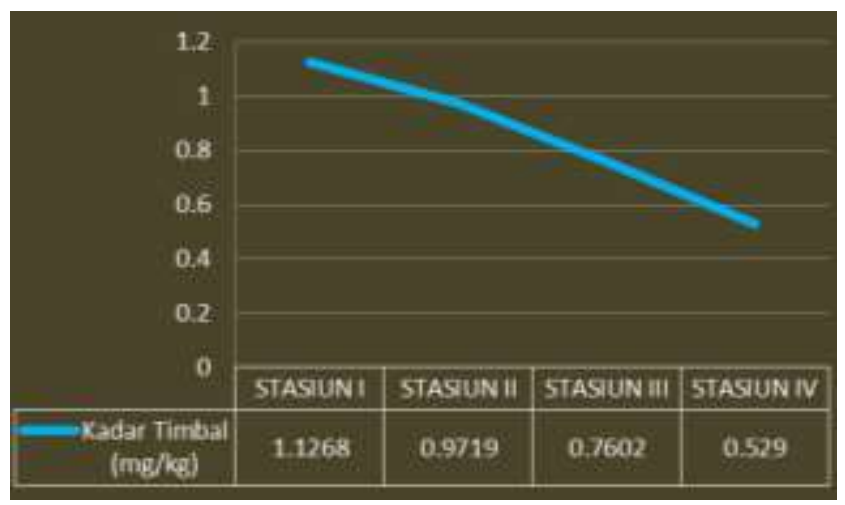

Figure 3. Concentrations of lead in sediment 


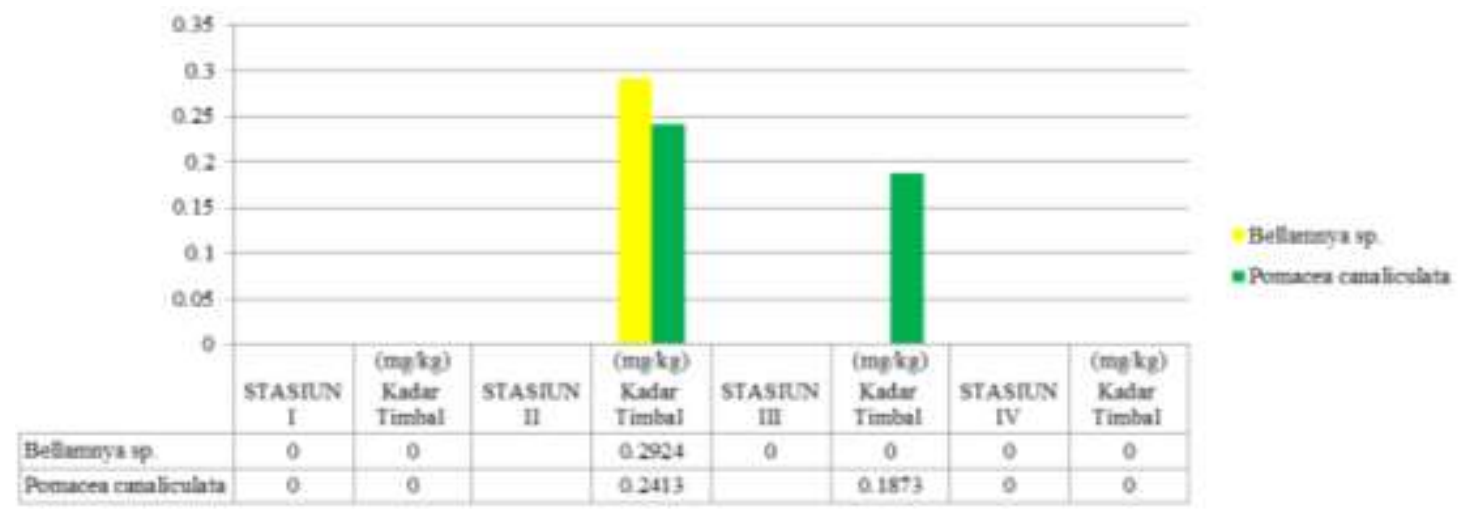

Figure 4. Lead levels in mollusks

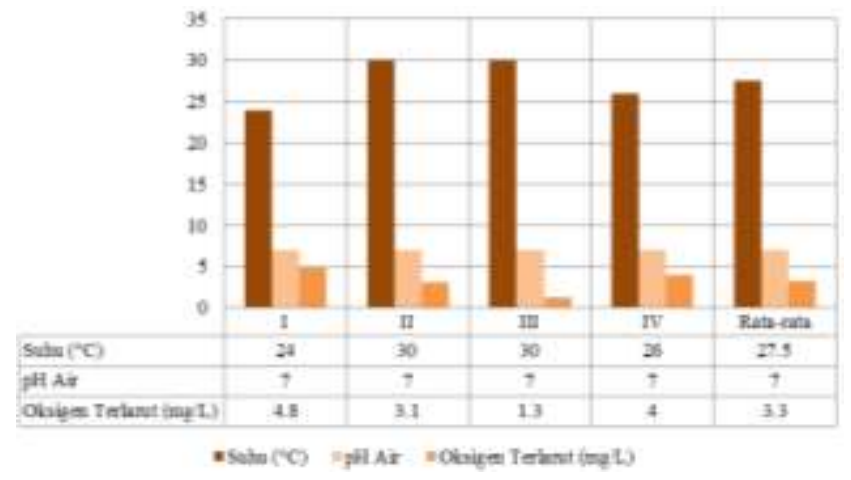

Figure 5. Environmental factors in the secondary irrigation channels

\section{Discussion}

The lead content in water in the secondary channel at the station I was $0.37 \mathrm{mg} / \mathrm{L}$, the lowest among the four stations. However, this level exceeds the threshold level set in the Government Regulation number 82 of 2001 concerning the quality standard for the level of lead in water, which is $0.03 \mathrm{mg} / \mathrm{L}$. The low level of lead at the station I was caused by pollutants from household waste only.

Household waste suspected of containing lead are batteries, children's toys, washed paint, and plastic food or beverage packaging (Lamondo 2020). Eshmat et al. (2014) also reported that the contamination of lead $(\mathrm{Pb})$ and cadmium $(\mathrm{Cd})$ in Ngemboh waters were caused by the disposal of resident waste originating from organic and non-organic materials. Budiastuti et al. (2016) also argue that household waste has a significant role in the presence of lead in waters.

Stations II and III had the highest levels of lead in the water, namely $1.30 \mathrm{mg} / \mathrm{L}$ and $1.69 \mathrm{mg} / \mathrm{L}$. Apart from receiving household waste, this canal also receives waste from motorized vehicle workshops and washing businesses. There are 15 workshops and 7 car washes discharging waste to the channel. It is suspected that the waste disposed of at secondary channels contains lead. Research conducted by Nadeak et al. (2015) found the lead level in the sample of liquid waste at 3 small workshops in
Tanjungpinang City were $0.6633 \mathrm{mg} / \mathrm{L}, 0.3423 \mathrm{mg} / \mathrm{L}$, and $0.2744 \mathrm{mg} / \mathrm{L}$, exceeded the threshold level.

The secondary irrigation channels at stations II and III also receive agricultural waste such as fertilizers and pesticides which contain lead. Research conducted by Sukarjo et al. (2018) found that applying fertilizers to rice plants can increase the content of lead in soil and rice plants.

The secondary irrigation channels at stations II and III are also close to roads with high motor vehicle mobilization producing smoke from the combustion engine, which crystallizes in the air, is carried away by the rain, and then enters the waterways. Research conducted by Reffiane et al. (2011) found that the concentration of lead in the air in the Semarang, which is densely populated with vehicles, as around 2-4 $\mu \mathrm{g} / \mathrm{Nm}^{3}$, whereas, in rural areas where the cars were less dense, it was less than 0.2 $\mu \mathrm{g} / \mathrm{Nm}^{3}$. The high concentration of lead in city air is due to the use of fuel that still contains tetraethyl lead (TEL) as an additive to increase the octane value of the fuel (Eshmat et al., 2014). Pratama et al. (2012) reported that the lead content in Tapak River ranged from 0.01 to $1.11 \mathrm{ppm}$, which was thought to come from motorized vehicle pollutants in water bodies.

The lead content in water at station IV was low, i.e., $0.38 \mathrm{mg} / \mathrm{L}$, due to the large channel size and the high current speed. High current velocity can cause dilution, which affects lead levels in the waters (Happy et al. 2012)

The lead content in gastropods, water, and sediment were higher than the lead content found in secondary data from DLHK Gorontalo province. The secondary data shows that the lead level in the water in the Bolango river, which is the source of water for irrigating the secondary irrigation channel, is $<0.002 \mathrm{mg} / \mathrm{L}$. The high lead content in this study is thought to be caused by waste disposal into secondary irrigation channels. Environmental parameters also affect the levels of heavy metal lead in water. The highest temperature occurred at station II, and station III, which was $30{ }^{\circ} \mathrm{C}$, and both stations also had the highest levels of lead in the water, namely $1.30 \mathrm{mg} / \mathrm{L}-1.69 \mathrm{mg} / \mathrm{L}$.

The lowest dissolved oxygen levels were found at stations II and III, namely $3.1 \mathrm{mg} / \mathrm{L}$ and $1.3 \mathrm{mg} / \mathrm{L}$, respectively, while the highest DO was found at stations I 
and IV, namely $4.8 \mathrm{mg} / \mathrm{L}$ and $4.0 \mathrm{mg} / \mathrm{L}$, respectively. A low DO concentration value can indicate that the waters are polluted. Yunitawati's (2012) research reported that dissolved oxygen in the Cantigi river ranged from 1.11-4.1 $\mathrm{mg} / \mathrm{L}$, indicating moderately polluted the Cantigi river.

Lead measurements were also carried out in the sediment because sediment is widely used to indicate the environment contaminated with metals in water (Ali et al., 2016). Research on heavy metals in sediment and water can measure the impact of metals produced by industry, households, and activities that can cause water pollution. The lead levels in the secondary channels ranged from $0.5290 \mathrm{mg} / \mathrm{kg}$ to $1.1268 \mathrm{mg} / \mathrm{kg}$, exceeding the threshold set by the Minister of Environment Regulation number 51 of 2004 , which is $0.07 \mathrm{mg} / \mathrm{kg}$.

Generally, the lead content in the sediment is higher than in the water because the heavy metals will settle in the sediment. Cahyani (2017) found that the levels of lead in water ranged from $0.042-0.104 \mathrm{mg} / \mathrm{kg}$ while in the sediment ranged from $1.56-1.98 \mathrm{mg} / \mathrm{kg}$. Environmental factors, namely temperature, influence the concentration of lead in the sediment. Happy (2012) states that the drop in water temperature will cause metals to settle into the sediments easily. Parallui (2013) also states that an increase in seawater temperature can reduce the absorption of heavy metals in fine particles from the pollution that settles on the bottom of the water. When the water temperature rises, heavy metal compounds will dissolve due to the decrease in settlement velocity into the particles. The lowest temperature in the secondary irrigation channel occurred at the station I, namely $24^{\circ} \mathrm{C}$.

Gastropods can be used as bioindicators of environmental pollution because they have low mobility characteristics, live in the bottom of the waters, and are filter feeders. Generally, Pomacea canaliculata and Bellamnya sp. filter the food around them. Widowati et al. (2019) state that golden snails get food by filtering food to accumulate lead.

Gastropods were found only in 2 observation stations, namely at stations II and III. At station II there were 2 species of Gastropods, namely Bellamnya sp. and Pomacea canaliculata and at station III, only 1 species, namely Pomacea canaliculata. Gastropods were found in only 2 stations because these stations have muddy substrates, which gastropods prefer, and are close to rice fields. Isnaningsih et al. (2011) state Pomacea canaliculata can be found in rice fields, lakes, or swamps, and these snails like muddy substrates. Sari et al. (2011) also state that Bellamnya sp. likes muddy substrates and running water.

The lead levels in gastropods ranged from 0.1873 $\mathrm{mg} / \mathrm{kg}$ to $0.2924 \mathrm{mg} / \mathrm{kg}$, much lower than the threshold set in SNI 7387: 2009 regarding the maximum limit of lead contamination in food, which is $1.0 \mathrm{mg} / \mathrm{kg}$. The lead content in gastropods was lower than the lead content in water, which was $0.37 \mathrm{mg} / \mathrm{L}$ to $1.69 \mathrm{mg} / \mathrm{L}$. This is in contrast with the results of research conducted by Wulandari et al. (2012) that the lead content in $S$. glomerata oysters was higher than in water, namely 0.505 $\mathrm{mg} / \mathrm{kg}-2,960 \mathrm{mg} / \mathrm{kg}$, and in water only $0.0035 \mathrm{mg} / \mathrm{L}-0.0470$ $\mathrm{mg} / \mathrm{L}$. Physiological processes probably cause a lower lead level in the gastropods than in the waters in the snail's body. The body of the snail has the protein metallothionein (MT), which can bind lead in the body. The MT residual thiols. There are 2 domains that function to bind different metals, namely $\alpha$ - and $\beta$ - (Smith et al. 2015)

Metallothionein is divided into 4 groups: MTI, MTII, MTIII, and MTIV. Metallothionein can be found in all living things such as bacteria, mammals, vertebrates, and invertebrates. MT can also be found in various body tissues such as kidneys, liver, testes, muscles, intestines, gills, blood, epithelial cells and urine. The MT concentration will increase if the organism accumulates more heavy metals in its body. After being detoxified, heavy metals will be excreted in the urine (Engel 1984).

The low level of lead in the snails' body compared to the level of lead in the water may also be caused by the small size of the snail, so the possibility of contact between the snails and the lead in the water was low. This was confirmed by Wulandari et al. (2012) who stated that the high $\mathrm{Pb}$ content in $\mathrm{S}$. glomerata oysters was influenced by the width, height, and length, and so, a large oyster was able to accumulate more metal than the small one. This study concluded that the lead levels in water, sediment and gastropods in the study sites exceeded the threshold set by the government.

\section{ACKNOWLEDGEMENTS}

With all humility, on this occasion, the author would like to express his deepest gratitude and highest appreciation to all people that make this research conducted.

\section{REFERENCES}

Ali MM, Ali ML, Islam MS, Rahman MZ. 2016. Preliminary assessment of heavy metals in water and sediment of Karnaphuli River Bangladesh. J Environ Nanotechnol Monit Manag 5: 27-35. DOI: 10.1016/j.enmm.2016.01.002

Baderan DW, Hamidun MS, Farid SM. 2019. The abundance, diversity and the density of mollusks in Tutuwoto mangrove area Og Anggrek Sub-district, North Gorontalo District, Gorontalo, Indonesia. GeoEco J 5 (1): 43-54. DOI: 10.20961/ge.v5i1.28652. [Indonesian]

Biahimo Y, Rumambi D, Ludong D, Pakasi S. 2015. Efficiency analysis of irrigation water distribution with geographical information system of Lomaya Dam Bone Bolango District, Gorontalo Province. Elementary Ejurnal 6 (15): 1-6. [Indonesian]

Budiastuti P, Raharjo M, Dewanti NAY. 2016. Analysis of lead-heavy metal pollution in Babon River Body, Genuk Sub-district, Semarang. J Public Health 4 (5): 119-125. [Indonesian]

Cahyani. 2017. Analysis of Lead Levels in Waters and River Sediments of Lesti, Malang District using Atomic Absorption Spectroscopy Methods. [Dissertation]. Universitas Islam Negeri Maulana Malik Ibrahim, Malang. [Indonesian]

Engel WD. 1984. Trace metal-binding proteins in marine molluscs and crustaceans. J Mar Environ Res 13 (3): 177-194. DOI: 10.1016/01411136(84)90029-1.

Eshmat ME, Mahasri G, Rahardja BS. 2014. Analysis of heavy metal content of lead $(\mathrm{Pb})$ and cadmium $(\mathrm{Cd})$ in green shells (Perna viridis L.) in Ngemboh Waters, Gresik District, East Java. Fish Mar Sci J 6 (1): 101-108. DOI: 10.20473/jipk.v6i1.11387. [Indonesian]

Happy, Arief RR. Masyamsir M, Dhahiyat Y. 2012. Distribution of PB and $\mathrm{Cd}$ heavy metal contents in water and sediment columns in the upper Citarum Watershed. J Fish Mar Affairs 3 (3): 175-182. [Indonesian] 
Isnaningsih NR, Marwoto RM. 2011. Pomacea pest snails in Indonesia: Morphological characters and their distribution (Mollusca Gastropoda: Ampullariidae). J Biol News 10 (4): 441-447.

Kitong MT, Abidjulu J, Koleangan HS. 2012. Analysis of mercury ( $\mathrm{Hg})$ and arsenic (As) in the Ranoyapo river sediment, Amurang Subdistrict, North Sulawesi. Journal of MIPA UNSRAT 1 (1): 16-19. DOI: 10.35799/jm.1.1.2012.425. [Indonesian]

Lamondo D, Soegianto A, Abadi A, Keman S. 2015. Antioxidant effects of ant nests (Myrmecodia pendans) on the apoptosis spermatogenic cells of rats exposed to plumbum. J Pharm Biol Chem Sci 5 (4): 1-14.

Lamondo D. 2020. Antioxidant Ant's Nest Reduces Plumbum Effects On Male Reproductive System. Ideas Publishing, Gorontalo. [Indonesian]

Nadeak, Erpina SM, Aldo N, Horiza H. 2015. Analysis of lead content $(\mathrm{Pb})$ in liquid waste in motor vehicle workshops in Tanjungpinang City. Journal of Poltekkes Jambi 10 (1): 82-86. [Indonesian]

Nur F, Karneli. 2015.The content of the heavy metal lead $(\mathrm{Pb})$ in the clam scales (Tridacna squmosa) around the Bira Ferry Port. Proceedings of the National Seminar on Health and Environmental Microbiology. [Indonesian]

Parallui N. 2013. Analysis of Heavy Metal Lead (Pb) Content in Langkitang (Faunus ater) in Maroneng Village Waters, Kec. Duampanua Kab. Areca. [Dissertation] Alauddin Makassar State Islamic University, Makassar. [Indonesian]

Pratama, Gandhi A, Pribadi, Rudhi, Lilik M. 2012. Heavy metal contents of $\mathrm{Pb}$ and $\mathrm{Fe}$ in water, sediment, and green shells (Perna viridis) in Tapak River, Tugurejo Village, Tugu Sub-district, Semarang City. J Mar Res 1 (1): 118-122.

Rangkuti MA. 2009. Analysis of $\mathrm{Hg}$, Cd, and $\mathrm{Pb}$ Heavy Metal Contents in Water and Sediment in the Waters of Panggang-Pramuka Island, Seribu Islands, Jakarta. [Hon. Thesis]. Bogor Agricultural University, Bogor. [Indonesian]

Reffiane F, Arifin MN, Santoso B. 2011. The impact of lead ( $\mathrm{Pb})$ content in the air on the intelligence of elementary school children. Majalah Ilmiah Pendidikan Dasar 1 (22): 97-107. DOI 10.26877/malihpeddas.v1i2.305. [Indonesian]

Saputra A. 2018. Bioaccumulation of the Heavy Metal Lead $(\mathrm{Pb})$ in Crab Shells (Polymesoda erosa) in Estuarine Waters of the Galacangange River, Suppa Sub-district, Pinrang District, South Sulawesi Province. Hasanuddin University, Makassar. [Indonesian]

Sari WP, Bahtiar, Emiyarti. 2016. A preference study of tutut snails (Bellamnya javanica) in Amonggedo Village, Konawe District. J Aquat Resour Manag 1 (2): 213-224.
Smith RD, Nordberg M. 2015. General Chemistry, Sampling, Analytical Methods, and Speciation. DOI: 10.1016/B978-0-444-59453-2.000020

Standar Nasional Indonesia. 2004. Method of test for lead (Pb) by acid digestion with Atomic Absorption Spectrophotometer (AAS). Badan Standarisasi Nasional. https://pesta.bsn.go.id on date 10/5/2020 [Indonesian]

Standar Nasional Indonesia. 2006. How to test bottled drinking water. Badan Standarisasi Nasional. https://lib.kemenperin.go.id on date 17/9/2020 [Indonesian]

Standar Nasional Indonesia. 2009. Maximum limit of heavy metal contamination in food. Badan Standarisasi Nasional. https://sertifikasibbia.com on date 18/11/2020 [Indonesian]

Standar Nasional Indonesia. 2009. Water and wastewater part 8: Method of testing for lead $(\mathrm{Pb})$ by Atomic Absorption Spectrophotometry (AAS). Badan Standarisasi Nasional. https://dspace.uii.ac.id on date 14/9/2020 [Indonesian]

Standar Nasional Indonesia. 2011. Determination of levels of heavy metals, lead $(\mathrm{Pb})$ and cadmium $(\mathrm{Cd})$ in fishery products. Badan Standarisasi Nasional. https://sentani.bkipm.kkp.go.id [Indonesian]

Sukarjo, Hidayah A, Zulaehah I. 2018. Effect of fertilizer on the accumulation and translocation of cadmium and lead in soil and plants. National Seminar on Biology and Science Education III. [Indonesian]

Wicaksono EA, Sriati, Lili W. 2016. Heavy metal lead $(\mathrm{Pb})$ in macrozoobenthos in Cirata Reservoir Waters, West Java Province. Jurnal Perikanan Kelautan 7 (1). [Indonesian]

Widowati H, Sutanto A, Sulistiani S. 2019. Nutritional potential against the dangers of heavy metals in mas snails (Pomacea canaliculata) and mussel shells (Anodonta woodiana). Edubiotic: Jurnal Pendidikan, Biologi dan Terapan 4 (01): 16-21. DOI: 10.33503/ebio.v4i01.293. [Indonesian]

Wulandari E, Herawati EY, Arifin D. 2012. Heavy metal contents of Pb in seawater and oyster Saccostrea glomerata as bioindicator of water quality in Prigi, Trenggalek, East Java. J Fish Res 1 (1): 1-5.

Yunitawati, Sunarto, Zaidah H. 2012. The relationship between substrate characteristics and the structure of the macrozoobenthos community in the Cantigi River, Indramayu District. J Fish Mar Affairs 3 (3): 221-227. 